\title{
A NOTE ON ECONOMICS
}

7 HE present hue and cry against the profiteer, whose elusive personality escapes arrest, and the discussion vehemently waged on the merits or demerits of " nationalization" divert attention from the root of the matter-the purpose or end of all productive labour.

Ignoring the fundamental, the campaign against profiteering is naturally unsuccessful, and the arguments for and against " nationalization" are frequently irrelevant.

The assumption that the present relations of capital and labour are, subject to slight modification, permanent, or, to put it in another way, that the directing control of labour must remain in the hands of the possessor of capital, commonly sways our minds. And this assumption, made somewhat rashly, largely prevents our clearing up present difficulties, or getting at the question of the purpose of production. Is the purpose private gain and profit? or the convenience and comfort of the community?

The assumption is rashly made and on quite insufficient evidence. Slavery for centuries, and as late as the nineteenth century in certain southern parts of the United States, was assumed as a permanent factor in society. Serfdom was assumed as permanent. The mighty structure of the Middle Ages we call feudalism seemed to possess the qualities of permanency. All these social arrangements, with their varying degrees of hardship and inequality, and their possibilities of tyranny and cruelty have passed; why should we assume that capitalism, i.e. the directing control of the labourer by the possessor of capital, is to last for all time? This capitalism is but a thing of a few hundred years' growth; begotten in the breakup of European society at the Reformation; born in the pride that contemned as foolishness authority claiming inspired supremacy on earth ; nourished on the ethics and philosophy of Protestant individualism; achieving its full stature in the hideous, heedless 


\section{A Note on Economics}

sacrifice of child-life in cotton factories at home, and the exploitation of countless aboriginal tribes in the dark corners of the earth. Such a system as this of capitalism not only cannot endure permanently (which of us would desire that it should ?), it is already far spent, destroying its own functions by its monstrous bulk. Hence, very greatly, our social discomforts, industrial unrests, labour troubles, high prices, housing problems, anti-profiteering campaigns, and discussions on " nationalization."

Indeed, if it were not that capitalism had run its course, as slavery, serfdom, and feudal systems ran theirs, and that its present failure were now plunging the world into a morass of unexpected difficulties, we might reasonably postpone the consideration of the why and wherefore of productive labour until a more convenient season, and leave the social question to be solved by the next generation. To-day any such postponement is impossible.

We cannot, if we would, throw responsibility to the winds, and declare we take no interest in social questions. We cannot for the most part profess pleasant contentment with our own lot, and take an equally pleasant satisfaction in the lot of our neighbour. Our neighbour won't allow it even were it possible for us to keep silent concerning our daily discontents. (It is certain, too, that the forces of anarchy, massed not for steady change and the gradual development of a new order in society, but for the deliberate overthrow of all existing institutions, religious, civic, and national, in the hope that out of the welter of destruction something better may emerge, have no intention of letting things alone; and if against the forces of anarchy the trained armies of men and women of good-will do not promptly contend, then are we assuredly undone.)

Lest any doubt that capitalism, for good and for evil, is no longer a successful working system, 


\section{Blackfriars}

let the evidence around us be examined, and the signs of the times discerned. The difficulty of imagining an industrial and social order not based on the capitalist in control of labour makes some minds fearful of what may be discerned, while the lesser and sordid fear of personal loss in power, and in the power that money confers, obstructs the vision of others.

But "things are what they are, and their consequences will be what they will be. Why then should we seek to be deceived ?" The one plain necessity is to establish justice, and to do this we must have a right judgment.

The directing control of labour and of the product of labour by the capitalist, widely resented in many quarters, no longer proves acceptable to the mass of people because it has ceased to effect its purpose. That is the situation. It is not that capitalism, in spite of its many unholy associations, is in itself evil. It is no more evil in itself than feudalism was. But like all human institutions, it contains the elements of change, and with its present monstrous growth of trusts, combines, and amalgamations it has become a positive menace to the liberties of mankind. It no longer ministers to the comfort of man; its failures are as apparent as its gigantic and swollen profits. And this failure compels us to question its continued existence, drives us to ask what is the purpose of labour-the end of all production ?

If we decide that labour must be employed not primarily for the satisfaction of human needs, but in order to supply employers with profits, let us face courageously the consequences of our decision.

First. All attempts to get rid of the profiteer will be vainly made. For the profiteer is no new thing, and his business is of the essence of capitalism. All through the nineteenth century profiteering was extolled by the professors of political economy at our 


\section{A Note on Economics}

ancient universities, and commended as the fine flower of our civilization by the orators and philosophers of liberalism. Robert Southey's early protests were a target for Macaulay's ridicule. The schemes of Robert Owen and his co-operative socialists for a new moral world wherein all should labour and all share the fruits of labour, were denounced as inimical to progress. John Ruskin attempting in Unto this Last to show that economics were not by any means mainly concerned with "buying in the cheapest market and selling in the dearest "- the accredited formula of the Manchester school-was compelled to cease writing for the Cornhill Magazine, the editor assuring him that the public wouldn't stand any more of it. That vast fortunes should be made in mills and factories, where young people were employed; in the owning of coal mines, ships, and workshops ; in the possession of slum property; and in other devious ways that brought riches quickly and kept multitudes miserably poor, was no more reprehensible than was the kidnapping and selling into slavery of African negroes by the famous buccaneers of the days of Queen Elizabeth. On the contrary, the money of the profiteer under Queen Victoria bought him knighthoods, baronetcies, and peerages. A title was considered a fitting climax to years of profiteering, an appropriate reward for the profiteer. And now, forsooth, the profiteer is assailed opprobriously; though why he is in the wrong now when, pursuing exactly the same methods, he was right twenty years ago, he may be reasonably excused for not understanding. But assail him as we may, he continues to ply his trade merrily enough. We may hedge the profiteer round with regulations, we may hamper and obstruct him in countless ways ; and with what result? That production and distribution will be even more hindered and obstructed; the confusion be increased; and 


\section{Blackfriars}

that profits so far from being diminished will be even multiplied. We cannot eliminate the profiteer and at the same time require him to exist. How can we prevent a man of energy, capacity, and peculiar aptitude for trade from developing his business, adding shop to shop, swallowing up less capable neighbours, and generally accumulating riches at the expense of rivals, possibly more scrupulous, but probably not more honest than himself ? A system of government control infinitely more vexatious than the proposals for the most bureaucratic form of State socialism would be required to keep such a man from expanding. $\mathrm{He}$ is a profiteer to-day because expansion brings profits and is impossible without profits under a system that declares the end of labour is the making of profits. But the man with a natural genius for trade and commerce (as other persons have a genius for scientific research, political organization, ecclesiastical administration) will follow his bent, not for private gain, but for the satisfaction of exercising his faculties, and would achieve his results for the community as heartily as for the limited liability company. The profiteer cannot be abolished as long as the making of profits is a recognised pursuit. He can be transformed into a public servant when the production and distribution of our common necessities is a co-operative business, conducted for all, with the whole nation as shareholders.

Secondly. The Nationalization of any particular industry, or of all industries, will not achieve very beneficial results if industry still remains in bondage to the making of profits. The employment of labour to provide revenue for the State might quite easily mean no improvement in our social conditions, and bring no advantage to labour. Instead of private persons getting the profits, a number of salaried officers of the State would require to be fed, clothed, 


\section{A Note on Economics}

and housed, at the public expense, and the nationalized industry would make the provision. It would be quite possible to displace the private capitalist and the private landlord by State officials whose salaries would equal the present takings in profit and rent, and whose services would not be a bit more useful to the community than those of the displaced ones. In that case labour would be no better off, and might easily be in a worse position, State officials having readier facilities for enforcing their demends. Nationalization by itself, then, while production and distribution are performed for the making of profits, promises no remedy for social unrest, and offers no hope of improved conditions.

Once we are clear that the employment of labour to achieve profits for private persons, or for the State, is attended by very definite evils to-day, we can look more favourably on its alternative - co-operative labour for the satisfaction of human needs. Human needs are few, however numerous be our wants. Food, raiment, and a dwelling-place, these and these alone are the temporal necessities of man. And yet because profits can be made more quickly in providing and distributing the unnecessaries, in gratifying the lusts and appetites of man, in tickling his fancy and indulging his latest whim-as though he were a convalescent or a spoilt child-we lack the very necessities.

Labour can neither employ itself on the land nor combine in co-operative employment, because we are told "it doesn't pay to grow corn in England!" But it pays to cultivate oyster beds, and to ransack the ends of the earth to provide dainties for fashionable restaurants where a dinner can be obtained at a guinea or more per head.

Clothes for everyday wear are hard to procure because it doesn't pay to make clothes for everybody. But it does pay to construct all manner of strange, 


\section{Blackfriars}

fantastic, and often scanty raiment that is purchased at amazingly high prices.

Houses and house-room are needed. But it doesn't pay to build houses for working people, or to let the working people build their own houses. It pays to erect cinemas, and more cinemas, and to decorate clubs ; the profits are greater from cinemas than from dwellinghouses, and clubs must be kept up, whatever happens.

Are we wrong, then, in suggesting that our immediate want is co-operation, not to make profits, but to build houses, grow food, and weave raiment ? And inasmuch as we are members, not of a small community but of a highly populated nation, of a federation of nations, haply soon of a League of Nations, our co-operative effort must be as wide as the nation, and include all its members. It may well be that the clergy and religious who minister to us in spiritual things will be excused from labouring at temporal things; that in return for the gifts of art and song, for the cunning devices of the artificer, for the patient studies of the scholar and scientist, the ministrations of physician and nurse, the play-acting of our professional entertainers, the law-giving of our appointed judges, the providing of current information, and other services deserving well of the community, labour will make ample return.

Meanwhile, the capitalist, bent on his profits, is entrenching himself in the highest places of the State in every land. And the anarchist in every land, bent on universal destruction, is arming. Both are certain that no divine law claims their obedience, and are ready for conflict.

If this conflict is to be avoided and all order and civilization and liberty not toppled into the abyss, cooperation must supersede capitalism, and production be directed to satisfying common needs.

Joserph Clayton. 